\title{
Parasite fauna of bream Abramis brama and roach Rutilus rutilus from a man-made waterway and a freshwater habitat in northern Germany
}

\author{
Sonja Rückert ${ }^{1,2, *}$, Sven Klimpel ${ }^{1}$, Harry Wilhelm Palm ${ }^{1}$ \\ ${ }^{1}$ Heinrich-Heine-University Düsseldorf, Institute of Zoomorphology, Cell Biology and Parasitology, Universitätsstr. 1, \\ 40225 Düsseldorf, Germany \\ ${ }^{2}$ Center for Tropical Marine Ecology (ZMT), Fahrenheitstr. 6, 28359 Bremen, Germany
}

\begin{abstract}
Fifty specimens each of bream Abramis brama and roach Rutilus rutilus were examined for metazoan parasite fauna and trichodinid ciliates; 25 specimens of each species were collected from the Kiel Canal, a man-made waterway, and a nearby freshwater lake, the Dieksee. This is the first detailed parasitological examination of $A$. brama and $R$. rutilus at these locations: 30 parasite species were found, comprising 4 protozoans, 4 myxozoans, 5 digeneans, 3 monogeneans, 2 cestodes, 6 nematodes, 2 acanthocephalans, 3 crustaceans and 1 hirudinean. The crustacean Caligus lacustris occurred in both habitats while 2 other crustacean species, 2 acanthocephalans and 1 hirudinean were recorded exclusively for the lake habitat. Larval as well as adult stages of the different parasite species were found, indicating that both fish species act as intermediate and final hosts in both habitats. The Kiel Canal (total of 17 parasite species) showed a lower parasite species richness for $A$. brama and $R$. rutilus (14 and 10 parasite species, respectively) than the lake (25 parasite species). A. brama had a higher parasite richness (22 species) than $R$. rutilus (16 species) in the lake habitat. Most parasites collected were of freshwater origin. Consequently, the observed infection pattern of both fish species in the waterway is mainly influenced by the limited salinity tolerance of freshwater parasites, which are negatively affected even by a salinity of 2.3 to 4.5 . In the central Kiel Canal, neither fish species was infected with marine parasites of low host specifity. These parasites are either limited by the low salinity at this sampling site $(<4.5$ to 6.0$)$ or they cannot enter the canal due to the environmental conditions prevailing in this artificial brackish water habitat. Thus, the canal may comprise a natural barrier preventing the distribution of North Sea parasites into the Baltic Sea. However, the brackish water Baltic Sea nematodes Paracuaria adunca and Cosmocephalus obvelatus were found in $R$. rutilus from the canal, demonstrating the ability of some parasite species to invade and extend their range of distribution through this man-made shipping route from the Baltic to the North Sea.
\end{abstract}

KEY WORDS: Kiel Canal · Waterway · Abramis brama $\cdot$ Rutilus rutilus $\cdot$ Parasite distribution · Salinity tolerance $\cdot$ Germany

\section{INTRODUCTION}

To date, there are approx. 29300 fish species described worldwide, of which about 12400 live predominantly in freshwater habitats (Froese \& Pauly 2006). Of these, 3 types are recognized: (1) primary freshwater fishes, unable to enter saltwater, (2) secondary freshwater species with weak salinity tolerance and the ability to enter brackish water habitats, and (3) peripheral freshwater fishes with a high salinity tolerance that are able to enter oceanic waters (Fiedler 1991). The bream Abramis brama and the roach Rutilus rutilus, two of the most common members of Cyprinidae in northern Europe, belong to the group of 
secondary freshwater species, and also inhabit the brackish Baltic Sea.

Previous parasitological studies in Europe described a wide spectrum of parasite species for Abramis brama and Rutilus rutilus (Palm et al. 1999, Moravec 2001). Most studies were carried out in freshwater habitats (lakes, rivers) in Great Britain, Finland, Poland, Russia, the Czech Republic and Hungary (e.g. Chappell \& Owen 1969, Pojmanska \& Dzika 1987, Reda 1987, Moravec et al. 1997, Moravec 2001). However, data on the parasite fauna from brackish water habitats is scarce (Rokicki 1975, Barkovskaya 1998). Valtonen et al. (2001) described the structure of the parasite component communities (assemblage of all parasite species within a single host species in an ecosystem) in the brackish water Baltic Sea, but did not describe their specific composition. In Germany most studies on the parasite fauna of A. brama and $R$. rutilus have been done in freshwater habitats in southern Germany (Kritscher 1979, 1983a,b, 1986a,b, Özcelik \& Deufel 1989). Lick (1991) and Kerstan (1992) presented the first record of a marine parasite species, Pseudoterranova decipiens (Krabbe, 1878) (P. decipiens [sensu stricto] after Zhu et al. 2002), a member of a sibling species complex, from the brackish water Kiel Canal, which connects the Baltic and the North Sea via the Elbe estuary. So far, 22 and 29 different parasite species, respectively, are known for both species from German coastal waters (Palm et al. 1999). There have been only a few studies on the parasite fauna of $A$. brama and $R$. rutilus from the northern part of Germany (Palm et al. 1999).

The Kiel Canal is a rarely studied man-made, busy shipping route connecting the North and Baltic Seas. It is $96.64 \mathrm{~km}$ long with a surface area of $1960 \mathrm{ha}$. The general movement of the water body in the canal is from east to west, with salinity decreasing from 15.0 in the eastern part to 2.5-3.0 in the middle, and increasing again to 4.5 in the western part. Salinity is influenced by the Baltic and North Seas and by freshwater inflows. Its fish fauna consists of euryhaline species of both freshwater and marine origin (Froese \& Pauly 2006), and few fish parasitological studies exist (Lick 1991, Kerstan 1992, Bazabas 1997).

The present study determined the parasite richness of the 2 most common cyprinids, Abramis brama and Rutilus rutilus, in the canal. A nearby freshwater lake, the Dieksee (a typical northern German freshwater environment) was studied for comparison. The parasite fauna of $A$. brama and $R$. rutilus have not previously been studied at these locations. The ability to spread North Sea fish parasites into the Baltic Sea, and Baltic Sea parasites into the North Sea through the canal was analysed, and the infection patterns of the 2 species were compared to determine possible differences and the reasons for any parasite diversity observed.

\section{MATERIALS AND METHODS}

Specimens of Abramis brama and Rutilus rutilus were collected by the RV 'Ratibor' during a monitoring project in the Kiel Canal at canal $\mathrm{km} 20.5$ to 57.7 $\left(53^{\circ} 53^{\prime} \mathrm{N}, 9^{\circ} 08^{\prime} \mathrm{W}\right)$ and 40.4 to $70.0\left(54^{\circ} 22^{\prime} \mathrm{N}\right.$, $10^{\circ} 08^{\prime} \mathrm{W}$ ), with salinities of 2.3 to 4.5 (A. brama collections) and 3.4 to 6.0 ( $R$. rutilus collections), respectively. Specimens from the Dieksee $\left(54^{\circ} 10^{\prime} \mathrm{N}\right.$, $10^{\circ} 31^{\prime} \mathrm{W}$ ) were obtained from local fishermen. The study area is shown in Fig. 1. Parasitological examination of 25 specimens of each species at each habitat (a total of 100 specimens) was carried out. All fishes were caught in May 2000 by trawl net in the canal and anchored gillnet in the lake.

Smears were taken from the gills and the inner opercula of live fishes. The fishes were stored on ice for 2 to $4 \mathrm{~h}$ during sampling on board the research vessel and then deep frozen at $-20^{\circ} \mathrm{C}$ in a store room until transfer to the laboratory in Kiel, where total fish length (TL, to the nearest $0.1 \mathrm{~cm}$ ) and total fish weight (TW, to the nearest $0.1 \mathrm{~g}$ ) were measured. The skin, fins, eyes, gills and the mouth and gill cavity were examined for ectoparasites. The digestive tract, liver, gall bladder, spleen, kidneys, gonads, heart and swim bladder were extracted and placed in saline solution. Internal organs were examined under a stereomicroscope, but the gall bladder was removed and studied by phase-contrast microscopy. Belly flaps and musculature were examined on a candling table.

Parasites were fixed in $4 \%$ borax-buffered formalin and preserved in $70 \%$ ethanol. The smears from the gills and the opercula were stained by silver nitrate

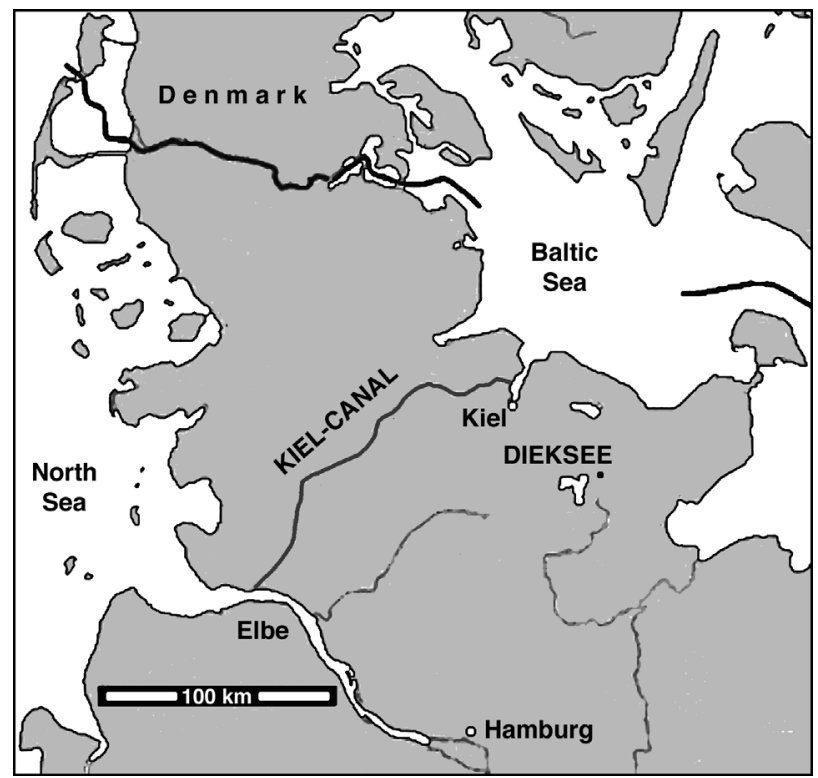

Fig. 1. Study area: the brackish Kiel Canal and the freshwater lake Dieksee 
impregnation after Klein $(1926,1958)$. The slides were rinsed and covered with $5 \%$ silver nitrate solution and impregnated for $30 \mathrm{~min}$ in the dark. Finally, the $\mathrm{AgNO}_{3}$ was removed and the slides were covered with distilled water and exposed to ultraviolet light for 40 to 50 min. The smears were dried after exposure and covered with Eukitt and a cover slip. Prior to fixation, Acanthocephala were transferred to fresh water until the proboscis everted. For identification, Nematoda and Acanthocephala were dehydrated in a graded ethanol series and transferred to $100 \%$ glycerine (Riemann 1988). Digenea, Monogenea and Cestoda were stained with acetic carmine, dehydrated, cleared with Eugenol or Creosote and mounted in Canada balsam. Crustacea were also dehydrated and transferred to Canada balsam. For parasite identification we followed standard identification literature and original descriptions. Voucher material of the parasites has been deposited in the Natural History Museum of Berlin (Museum für Naturkunde der Humboldt-Universität zu Berlin) under ZMB Entozoa Nos. 7404 to 7418 . The parasitological terms (prevalence, abundance, intensity, mean intensity) follow those of Bush et al. (1997).

\section{RESULTS}

A total of 30 different parasite species were collected from both habitats and fish species. In the Kiel Canal, the component community of Rutilus rutilus and Abramis brama comprised 10 and 14 parasite species, respectively. In the Dieksee the numbers were higher, with 16 and 22 parasite species, respectively. Data on the prevalence, abundance, intensity and site of infection together with the salinity preference of the parasite species is summarized in Table 1. Details of parasite infection and comments on parasite distribution are given below.

\section{Protozoa}

Protozoans belonging to the Order Peritrichida (Trichodinidae) were identified as Trichodina modesta Lom, 1970, T. prowazeki Grupcheva \& Lom, 1980, Trichodina sp. and Paratrichodina incissa (Lom, 1959). The only protozoan species in the Kiel Canal was $T$. prowazeki in both Abramis brama and Rutilus rutilus. T. modesta was the most common trichodinid ciliate infesting $A$. brama from the Dieksee. This species was absent from specimens from the canal. A single specimen of A. brama (from the lake) was infested with Trichodina sp. at low prevalence and abundance. Paratrichodina incissa was also found on the gills of a single specimen each of $A$. brama and $R$. rutilus (both from the lake). More trichodinid ciliate species infested the gills and opercula of fishes from the freshwater lake than fishes from the brackish water canal.

\section{Myxozoa}

We found 4 species of myxozoans in gill filaments or the gallbladder of Abramis brama or/and Rutilus rutilus. Myxobolus sp. (Myxobolidae) (gills) was present at a high prevalence and was the only species found in fish ( $A$. brama only) from both the fresh- and the brackish water habitats. Ceratomyxa sp. (Ceratomyxidae) (gallbladder) infected both $A$. brama and $R$. rutilus (Dieksee), at a medium high prevalence. Zschokkella nova Klokacheva, 1914 (Myxidiidae) was collected from the gallbladder of A. brama, and Myxobolus diversicapsularis Slukhai in Shulman, 1966 was isolated from the gill filaments of $R$. rutilus, both from the lake. More myxozoan parasites occurred in the lake than in the canal

\section{Digenea}

We isolated 5 digenean species: metacercaria stages of Diplostomum cf. spathaceum (Rudolphi, 1819), Posthodiplostomum cf. cuticola (von Nordmann, 1832) (both Diplostomidae) and Ichthyocotylurus cf. platycephalus (Creplin, 1852) (Strigeidae) as well as adult stages of Sphaerostoma bramae (Müller, 1776) (Opecoelidae) and Asymphylodora demeli Markowski, 1935 (Lissorchiidae). Diplostomum cf. spathaceum and $P$. cf. cuticola were present in both fish species and both habitats. With the exception of $D$. cf. spathaceum in Abramis brama, their prevalence and abundance in the lake was higher than in the canal. Asymphylodora demeli occurred in Rutilus rutilus from the canal, whereas $S$. bramae was present in A. brama from the lake. Ichthyocotylurus cf. platycephalus was found in both habitats, with a higher prevalence in A. brama from the lake. More digeneans occurred in fishes from the freshwater habitat than in those from the canal.

\section{Monogenea}

The monogeneans were represented by members of 3 genera, Dactylogyrus spp. (Dactylogyridae), Diplozoon paradoxum von Nordmann, 1832 and Paradiplozoon rutili (Gläser, 1967) (both Discocotylidae). The specimens collected were all adults, and all 3 species occurred in both the freshwater and brackish water habitats. Each specimen of Rutilus rutilus from the lake was infested with Dactylogyrus spp. Diplozoon para- 


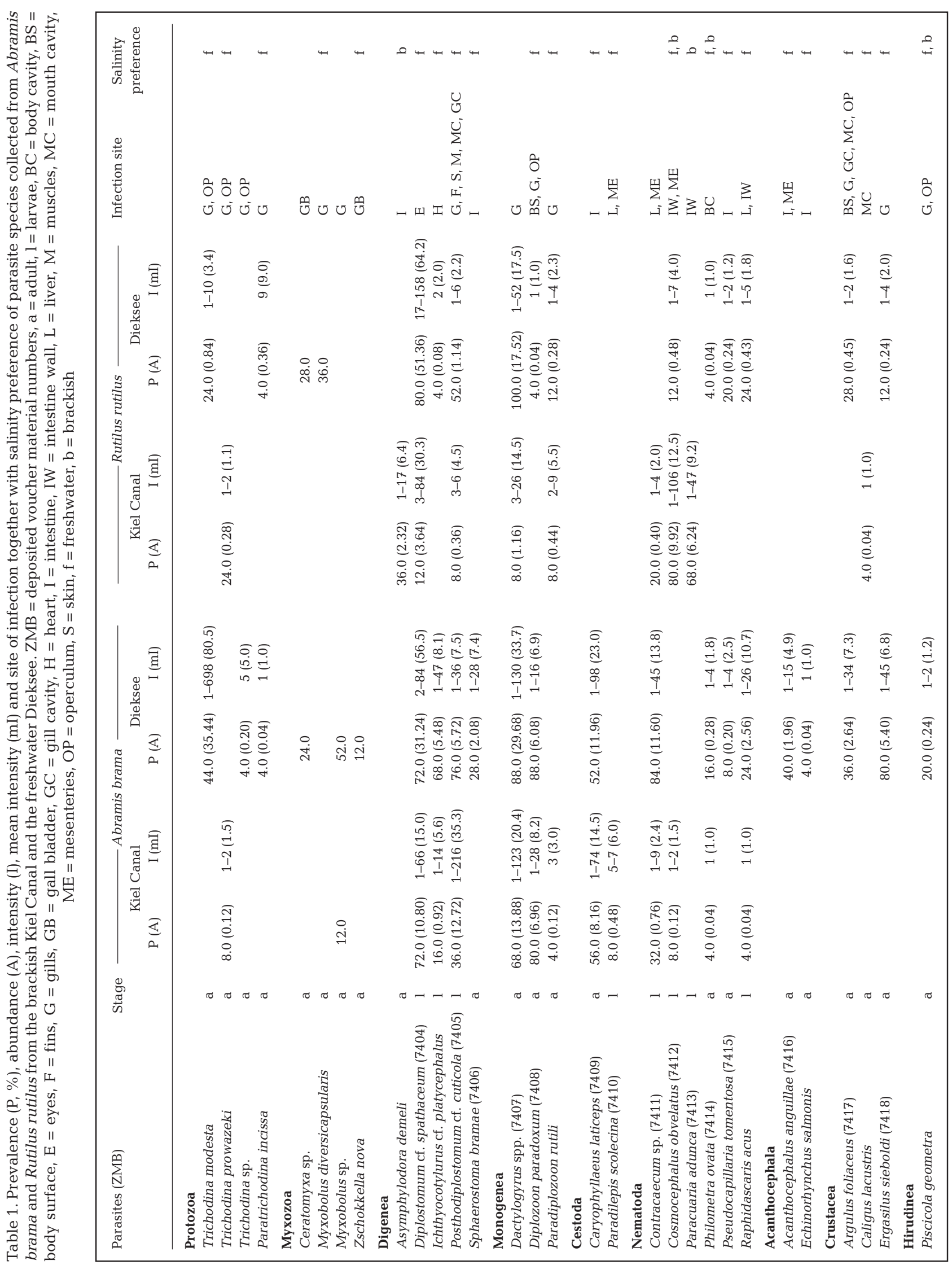


doxum had a high prevalence in Abramis brama caught in the lake and the canal, whereas a single infested specimen of $R$. rutilus was caught in the lake. High infestation with $P$. rutili was found in lake $R$. rutilus. However, its prevalence and abundance was low. A single specimen of $A$. brama (Kiel Canal) was infested with $P$. rutili. The prevalence of the Monogenea was higher in the freshwater than in the brackish water habitat.

\section{Cestoda}

Cestodes were collected from Abramis brama, but were totally absent from Rutilus rutilus. Two species were isolated: adult Caryophyllaeus laticeps (Pallas, 1781) (Order Caryophyllidea) (both habitats), and larval Paradilepis scolecina (Rudolphi, 1819) (Order Cyclophyllidea) (canal only, at low prevalence and abundance).

\section{Nematoda}

The Nematoda was the most diverse taxon found during the present study, being represented by both larval and adult specimens: larval Contracaecum sp. and Raphidascaris acus (Bloch, 1779) (Anisakidae); adult Pseudocapillaria tomentosa (Dujardin, 1843) (Capillariidae); larval Cosmocephalus obvelatus (Creplin, 1825) and Paracuaria adunca (Creplin, 1846) (both Acuariidae); and adult Philometra ovata (Zeder, 1803) (Philometridae). With the exception of $P$. tomentosa (Dieksee) and P. adunca (Kiel Canal), all other species occurred in fishes from both habitats. Contracaecum sp. was the most abundant species, with a high prevalence of infection in Abramis brama from the lake. For Rutilus rutilus, the most abundant species was C. obvelatus, reaching a high prevalence in the canal; this was the only species that was collected from $R$. rutilus from both habitats. Paracuaria adunca was found in $R$. rutilus (canal). In contrast to $C$. obvelatus and $P$. adunca, the other 4 species were more abundant in the freshwater lake.

\section{Acanthocephala}

Two adult acanthocephalan species were present in one of the fish species studied. Acanthocephalus anguillae (Müller, 1780) and Echinorhynchus salmonis Müller, 1784 (both Echinorhynchidae) were collected from Abramis brama from the lake but not from the canal. They were not present in Rutilus rutilus from either habitat. A. anguillae was present at a medium high prevalence, whereas E. salmonis was found only in a single specimen of $A$. brama.

\section{Crustacea}

Adult stages of Argulus foliaceus (Linné, 1758) (Argulidae), Ergasilus sieboldi von Nordmann, 1832 (Ergasilidae) and Caligus lacustris (Steenstrup \& Lütken, 1861) (Caligidae) were recorded. The most abundant species was the copepod E. sieboldi, which had a high prevalence of infestation on Abramis brama in the lake. A. foliaceus and E. sieboldi occurred only in fishes from the lake; it infested both fish species, but at higher prevalences for A. brama. A single specimen of C. lacustris was collected from Rutilus rutilus from the Kiel Canal.

\section{Hirudinea}

Piscicola geometra (Linné, 1761) (Piscicolidae) was the only hirudinean species found-on Abramis brama from the lake. This (adult) species was present at low prevalence and was not found on A. brama from the canal, nor on Rutilus rutilus from either habitat.

\section{DISCUSSION}

Abramis brama and Rutilus rutilus from the brackish Kiel Canal and the freshwater Dieksee displayed a highly diverse parasite fauna, comprising 4 protozoan and 26 metazoan parasite species. Of these 30 species, 19 were endoparasitic and 11 ectoparasitic. Both fishes served as intermediate as well as final hosts in both locations. A. brama sampled from the Dieksee had the most species-rich parasite fauna, hosting 22 parasite species (component community). In contrast, $R$. rutilus from the Kiel Canal had the lowest richness with 10 parasite species. Fig. 2 presents the number of parasite species collected from both fish species at both locations (infra community, i.e. assemblage of all parasite species within an individual host), and shows that species richness was higher in the lake than the canal for both $A$. brama and $R$. rutilus. For the Kiel Canal, 12 and 8 new locality records were established for $A$. brama and $R$. rutilus, respectively; 17 and 14 new locality records were established for the Dieksee.

According to Remane (1940), brackish water contains fewer aquatic animals than seawater or freshwater, and is considered a separate habitat, not a mere link between fresh- and saltwaters. Species diversity in brackish waters is low (Remane 1940). According to Grabda (1991) and Palm (2004), diversity of parasites 


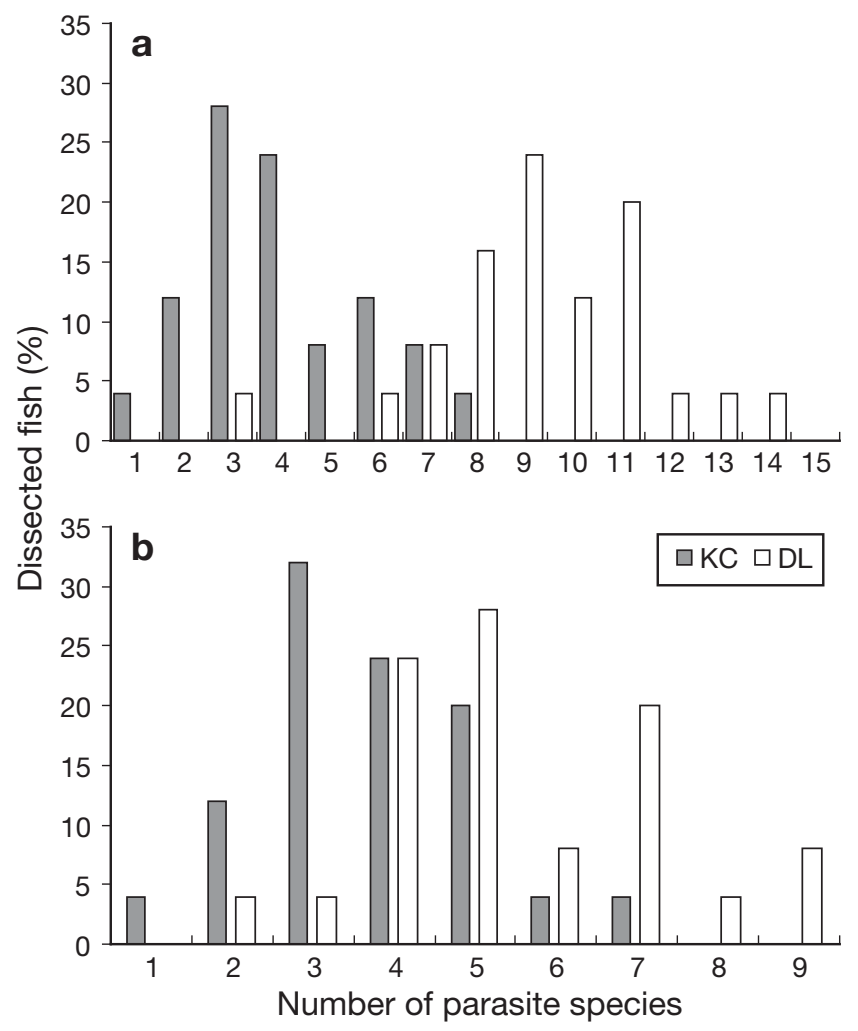

Fig. 2. (a) Abramis brama and (b) Rutilus rutilus. Number of parasite species infecting bream and roach in the brackish water Kiel Canal (KC) and freshwater lake Dieksee (DL)

of marine fishes is much higher than that of freshwater fishes. The influence of salinity on fish parasites was studied in detail by Osmanov \& Yusupov (1985), who gave special attention to the changes in the parasite fauna of fishes from Lake Aral, which accompanied increasing salinity during the last 5 decades. They reported a decrease in the composition, number (richness) and intensity of infection of parasite species as a function of changing salinity levels.

\section{Abramis brama}

Abramis brama displayed the most diverse parasite fauna in freshwater, with 22 parasite species in specimens from the freshwater lake Dieksee and 14 parasite species in specimens from the Kiel Canal. According to Palm et al. (1999), there are 22 different metazoan parasite species in German coastal waters. Moravec et al. (1997) collected 18 parasite species from A. brama from the Vlatava River in the Czech Republic. A total of 37 parasite species were isolated from specimens from the Vistula River in Poland (Reda 1987). Thus, A. brama from the Kiel Canal displays low parasite richness compared to individuals from the freshwater lake.
Fig. 2a shows that generally 3 to 4 parasite species (infra community) were collected from the 25 specimens of Abramis brama from the canal, whereas 8 to 11 parasite species infected most specimens from the lake. With the exception of Trichodina prowazeki, A. brama from the Dieksee was infected by all parasite species that were also collected from the Kiel Canal. The parasites isolated were predominantly freshwater species. The increased salinity levels (between 2.3 and 4.5) at the sampling sites in the canal, as compared to the freshwater habitat, severely affected the distribution of the parasite fauna of A. brama. According to Möller (1978), Hahnenkamp \& Fyhn (1985) and Knudsen \& Sundnes (1998), metazoan ectoparasites are sensitive to any salinity change. This could be one reason for the lack of the ectoparasitic taxa Crustacea and Hirudinea on fishes from the Kiel Canal during the present study.

Endoparasitic helminths are also affected by increases in salinity, as again exemplified by the Kiel Canal. Parasite species found in both habitats were generally more highly prevalent in the lake (Table 1). For example, metacercariae of Ichthyocotylurus cf. platycephalus and Posthodiplostomum cf. cuticola were found in fishes from the Dieksee at a prevalence of 68.0 and $76.0 \%$ and an abundance of 5.48 and 5.72 , respectively, compared with a prevalence of 16.0 and $36.0 \%$ and abundance of 0.92 and 12.72 , respectively, for the fishes from the Kiel Canal. Similarly, the larval nematode Contracaecum sp. had a prevalence and abundance of $84.0 \%$ and 11.60 in the lake and only $32.0 \%$ and 0.76 in the canal. The prevalence of Diplostomum cf. spathaceum in both habitats was $72.0 \%$; however, the abundance and mean intensity of this parasite in the lake was much higher (31.24 and 56.6) than in the Kiel Canal (10.80 and 15.0). There are several reasons for these differences. Salinity can negatively affect the distribution of the first intermediate hosts (e.g. the molluscs Planorbis sp. and Valvata piscinalis) of the digeneans Posthodiplostomum cf. cuticola and I. cf. platycephalus resulting in reduced transmission to the second intermediate host in the Kiel Canal. Digeneans also have free swimming larval stages (miracidium, cercaria) that hatch from the egg or leave the snail as first intermediate host, to actively swim and infect possible intermediate hosts. Successful transmission (e.g. of the cercariae of $P$. cf. cuticola and $I$. cf. platycephalus) could be reduced if salinity were to affect their host-locating mechanism or their survival time in the water. Another cause for low infection with $D$. cf. spathaceum and P. scolecina could be low abundance of the intermediate hosts (whereby the first intermediate host comprises gastropods Lymnea spp. or cyclopoid copepods and the second intermediate host cyprinid fish species) or the definitive hosts (i.e. 
the cormorant Phalacrocorax carbo) in the Kiel Canal. Thus far, no Lymnea species has been detected in the Kiel Canal (Bothmann 1998, Deutschmann 1999). Infection could take place during migrations of the fishes into adjacent freshwater habitats, resulting in different infection levels according to the duration and location of their sojourn in freshwater. It is interesting that Acanthocephala were absent from Abramis brama from the brackish water Kiel Canal. Some acanthocephalan species such as Pomphorhynchus laevis (Müller, 1776) complete their life cycles in freshwater and in marine habitats (Möller \& Anders 1983). However, Acanthocephalus anguillae and Echinorhynchus salmonis seem to be truly freshwater parasites.

\section{Rutilus rutilus}

Similar to Abramis brama, specimens of Rutilus rutilus from the Dieksee had a higher parasite richness (16 parasite species, component community) than specimens from the canal (10 parasite species). Valtonen et al. (1997) collected 38 parasite species from $R$. rutilus from 4 lakes in Finland, and Moravec et al. (1997) isolated 21 parasite species from $R$. rutilus from the Vlatava River in the Czech Republic. Palm et al. (1999) listed 29 parasite species in $R$. rutilus from German coastal waters, whereas a total of 24 parasite species were found in different brackish water habitats by Rokicki (1975) and Barkovskaya (1998) in Poland and Finland, respectively. Fig. 2b shows that generally 3 to 5 parasite species were present in each roach (infra community) from the Kiel Canal, while 4 to 7 parasite species were isolated from roach from the Dieksee. Although the difference in parasite species richness between the 2 habitats is lower for $R$. rutilus than for $A$. brama, it is nevertheless clearly evident.

In most cases, the parasite species found in Rutilus rutilus corresponded to those found in Abramis brama, with a few exceptions. Cestodes, acanthocephalans and hirudineans were not found in $R$. rutilus from both habitats. $R$. rutilus from the Kiel Canal originated from sampling sites with a salinity of 3.4 to 6.0. In most cases, parasites that were present in roach collected from both habitats showed lower prevalence in canal specimens, e.g. the digenean Diplostomum cf. spathaceum, with a prevalence of $80.0 \%$ and an abundance of 51.36 in lake roach compared with a prevalence of $12.0 \%$ and abundance of 3.64 in canal roach, and the monogeneans Dactylogyrus spp., with a prevalence and abundance of $100.0 \%$ and 17.52 in lake roach and $8.0 \%$ and 1.16 in canal roach, differences that arise from the direct effect of salinity on Dactylogyrus spp., as well as the first intermediate host or the parasitic stage(s) of Diplostomum cf. spathaceum. In contrast, parasite prevalences for these species in bream $A$. brama were similar in the canal and the lake.

The salinity tolerance of Rutilus rutilus is higher than that of Abramis brama. As the former can spend its life cycle entirely within the Kiel Canal, migration into freshwater (e.g. for spawning) is not necessary. Therefore, the possibility of becoming infected with parasites from adjacent freshwater habitats is lower for $R$. rutilus than for A. brama, which spawns exclusively in freshwater. This could be a reason for the lower parasite richness observed in $R$. rutilus, in addition to slight differences in the feeding ecology of the 2 species. On the other hand, some parasites can be positively affected by slightly increased salinity. The nematode Paracuaria adunca had a prevalence of $68.0 \%$ and an abundance and mean intensity of 6.24 and 9.2 in $R$. rutilus from the brackish water canal, but was absent in specimens from the freshwater lake. The nematode Cosmocephalus obvelatus was present at a prevalence of $80.0 \%$ (abundance 9.92) and a mean intensity of 12.5 in roach from the Kiel Canal during the present study. The typical intermediate hosts for both parasites are crustaceans such as amphipods (e.g. Wong \& Anderson 1982, Jackson et al. 1997), which comprise part of the diet of $R$. rutilus. A difference in the occurrence of intermediate hosts at the 2 sampling locations could be a possible reason for the high prevalence of $P$. adunca and $C$. obvelatus in roach from the Kiel Canal, and comprise an example of brackish water parasites from the Baltic Sea invading the mainly freshwater-dominated Kiel Canal. In contrast, no parasite species from the North Sea was found in $R$. rutilus from the central part of the canal.

\section{CONCLUSIONS}

The present study has demonstrated that Abramis brama and Rutilus rutilus from the freshwater Dieksee were infected with more parasite species than specimens from the Kiel Canal. Although the hydrology of the canal is highly influenced by the Baltic and North Seas, the parasite fauna of the 2 fish species consists mainly of freshwater parasites. Typical North Sea fish parasites were not detected, indicating that the Kiel Canal (a man-made shipping route) may act as a barrier, preventing the movement of potential parasitic invaders from the North Sea to the Baltic Sea. The primary reason for this is the low salinity in the middle of the canal, which prevents the spread of marine parasites and/or their intermediate hosts. In contrast, 2 Baltic Sea parasites were recorded at a high prevalence in $R$. rutilus at both sampling sites. Thus, some Baltic Sea fish parasites may use the Kiel Canal to extend their range of distribution to the River 


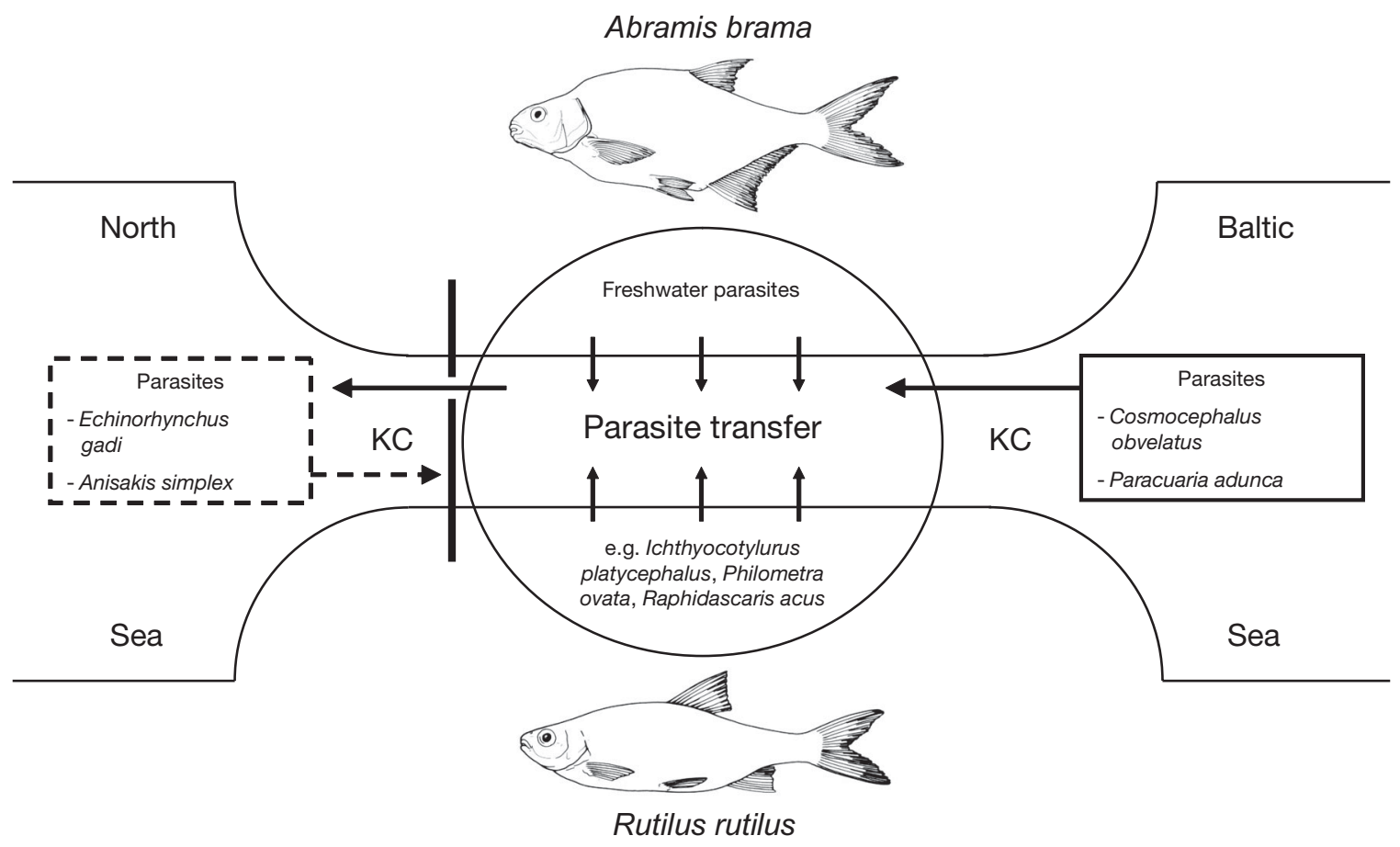

Fig. 3. Abramis brama and Rutilus rutilus. Transmission pathways of parasites infecting bream and roach in the Kiel Canal (KC) and adjacent bodies of water. Echinorhynchus gadi (Acanthocephala) and Anisakis simplex (Nematoda) are examples of typical marine parasites

Elbe, the Elbe Estuary and, possibly, the North Sea (Fig. 3). Both A. brama and $R$. rutilus are benthic, omnivorous species with high parasite diversity but low potential as parasite transporters between the 2 seas connected by the canal. Future studies should examine carnivorous species such as pikeperch Stizostedion lucioperca, European perch Perca fluviatilis and ruffe Gymnocephalus cernua (Perciformes: Percidae) and analyse their potential as parasite transporters in the canal from the North Sea towards the Baltic Sea or vice versa. This would contribute to our understanding of the role of man-made waterways in the transport of fish parasite populations into formerly non-infected habitats.

Acknowledgements. We thank the resident fishermen at the Dieksee for collecting the fish used in this investigation, and R. Kafemann (leader of the monitoring project in the Kiel Canal) for the opportunity to accompany him on one of his cruises, during which the fish samples were taken. We appreciate the detailed comments of 3 anonymous referees.

\section{LITERATURE CITED}

Barkovskaya VV (1998) Changes of a parasite fauna in the perch Perca fluviatilis and the roach Rutilus rutilus in the Neva river estuary of the Finnish Bay during a long period. Parazitologiya 32:52-58

Bazabas C (1997) Nahrungs- und Parasitenuntersuchungen von zwei Grundelarten (Pomatoschistus minutes und $P$. microps) im Nord-Ostsee-Kanal (Gobiidae, Teleostei). MS thesis, University Hamburg

Bothmann O (1998) Epifauna und Pfahlbewuchs im Salzgehaltsgradienten des Nord-Ostsee-Kanals. MS thesis, Christian-Albrechts University Kiel

Bush AO, Lafferty KH, Lotz JM, Shostak AW (1997) Parasitology meets ecology on its own terms: Margolis et al. revisited. J Parasitol 83:575-583

Chappell LH, Owen WR (1969) A reference list of parasite species recorded in freshwater fish from Great Britain and Ireland. J Nat Hist 3:197-216

Deutschmann K (1999) Untersuchungen zur Infauna des Makrozoobenthos im Salzgehaltsgradienten des NordOstsee-Kanals. MS thesis, Christian-Albrechts University Kiel

Fiedler K (1991) Fische. In: Kaestner A (ed) Lehrbuch der speziellen Zoologie. 2. Teil, Bd. II. Gustav Fischer Verlag, Stuttgart, p 1-498

Froese R, Pauly D (eds) (2006) FishBase. World Wide Web electronic-publication. Available at: www.fishbase.org $(02 / 2006)$

Grabda J (1991) Marine fish parasitology: an outline. VCH-Verlag, Weinheim

Hahnenkamp L, Fyhn HJ (1985) The osmotic response of salmon louse, Lepeophtheirus salmonis (Copepoda: Caligidae), during the transition from sea water to fresh water. J Comp Physiol B 155:357-365

Jackson CJ, Marcogliese DJ, Burt MDB (1997) Role of hyperbenthic crustaceans in the transmission of marine helminth parasites. Can J Fish Aquat Sci 54: $815-820$

Kerstan SL (1992) Der Befall von Fischen aus dem Wattenmeer und dem Nordatlantik 1988-1990 mit Nematodenlarven und einer Bibliographie über parasitische Nemato- 
den in Fischen und Seesäugern. Ber Inst Meereskd Kiel 219:1-205

Klein B (1926) Ergebnisse mit einer Silbermethode bei Ciliaten. Arch Protistenkd 56:243-279

Klein B (1958) The 'dry' silver method and its proper use. J Protozool 5:99-103

Knudsen KK, Sundnes G (1998) Effects of salinity on infection with Laerneocera branchialis (L.) (Copepoda: Pennelidae). J Parasitol 84:700-704

Kritscher E (1979) Die Fische des Neusiedlersees und ihre Parasiten, III. Acanthocephala. Ann Nathist Mus Wien B 83:641-650

Kritscher E (1983a) Die Fische des Neusiedlersees und ihre Parasiten, IV. Nematoda. Ann Nathist Mus Wien B 84: 123-126

Kritscher E (1983b) Die Fische des Neusiedlersees und ihre Parasiten, V. Trematoda: Digenea. Ann Nathist Mus Wien B 85:117-131

Kritscher E (1986a) Die Fische des Neusiedlersees und ihre Parasiten, VI. Cestoidea. Ann Nathist Mus Wien B 90: 183-192

Kritscher E (1986b) Die Fische des Neusiedlersees und ihre Parasiten, VII. Trematoda: Monogenea und Zusammenfassung. Ann Nathist Mus Wien B 90:407-421

Lick R (1991) Untersuchungen zu Lebenszyklus (Krebse Fische - marine Säuger) und Gefrierresistenz anisakider Nematoden in Nord- und Ostsee. Ber Inst Meereskd Kiel 218:1-195

Möller H (1978) The effects of salinity and temperature on the development and survival of fish parasites. J Fish Biol 12:311-323

Möller H, Anders K (1983) Krankheiten und Parasiten der Meeresfische. Verlag Heino Möller, Kiel

Moravec F (2001) Checklist of the metazoan parasites of fishes of the Czech Republic and the Slovak Republic (1873-2000). Academia, Praha

Moravec F, Gelnar M, Ergens R, Scholz T (1997) Metazoan parasites of fishes from the section of the Vlatava River supposed to be affected by the operation of the Temelin nuclear electric power-station, Czech Republic. Acta Soc Zool Bohemoslov 61:65-76

Osmanov SO, Yusupov O (1985) Influence of salinity increa-

Editorial responsibility: Robin Overstreet,

Ocean Springs, Mississippi, USA sing of the Aral Sea on the parasite fauna. Parazitol Sb 33:14-43

Özcelik A, Deufel J (1989) Untersuchungen über fischparasitäre Würmer im Bodensee. Z Angew Zool 76:27-59

Palm HW (2004) The Trypanorhyncha Diesing, 1863. PKSPLIPB Press, Bogor

Palm HW, Klimpel S, Bucher C (1999) Checklist of metazoan fish parasites of German coastal waters. Ber Inst Meereskd Kiel 307:1-148

Pojmanska T, Dzika E (1987) Parasites of bream (Abramis brama L.) from the Lake Goslawskie (Poland) affected by long-term thermal pollution. Acta Parasitol Pol 32: 139-161

Reda ESA (1987) An analysis of parasite fauna of bream, Abramis brama (L.) in Vistula near Warszawa in relation to the character of fish habitat. I. Review of parasite species. Acta Parasitol Pol 32:309-326

Remane A (1940) Einführung in die zoologische Ökologie der Nord- und Ostsee. Geest \& Portig, Leipzig

Riemann F (1988) Nematoda. In: Higgins RP, Thiel H (eds) Introduction to the study of meiofauna. Smithsonian Institution Press, Washington, DC, p 293-301

Rokicki J (1975) Helminth fauna of fishes of the Gdansk Bay (Baltic Sea). Acta Parasitol Pol 23:37-84

Valtonen ET, Holmes JC, Koskivaara M (1997) Eutrophication, pollution, fragmentation: effects on parasite communities in roach (Rutilus rutilus) and perch (Perca fluviatilis) in four lakes in central Finland. Can J Fish Aquat Sci 54: 572-585

Valtonen ET, Pulkkinen K, Poulin R, Julkunen M (2001) The structure of parasite component communities in brackish water fishes of the northeastern Baltic Sea. Parasitology 122:471-481

Wong PL, Anderson RC (1982) The transmission and development of Cosmocephalus obvelatus (Nematoda: Acuarioidea) of gulls (Laridae). Can J Zool 60:1426-1440

Zhu XQ, D'Amelio S, Palm HW, Paggi L, Geroge-Nascimento M, Gasser RB (2002) SSCP-based identification of members within the Pseudoterranova decipiens complex (Nematoda: Ascaridoidea: Anisakidae) using genetic markers in the internal transcribed spacers of ribosomal DNA. Parasitology 124:615-623

Submitted: March 17, 2006; Accepted: November 20, 2006 Proofs received from author(s): March 6, 2007 